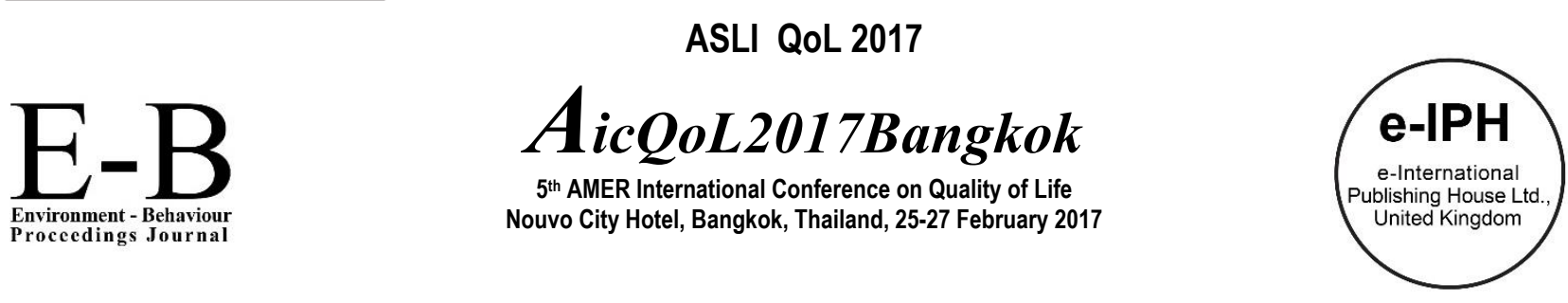

\title{
Visual Landscape Assessment for Development Landscape Structure: Case study at Taiping, Perak
}

\author{
Mohd Zulhaili Teh ${ }^{1 *}$, Noorsazwan Ahmad Pugi ${ }^{2}$, Norhafizah Abdul Rahman ${ }^{3}$ \\ ${ }^{1}$ Faculty of Architecture, Planning \& Surveying, Universiti Teknologi MARA, Seri Iskandar Campus, Seri Iskandar, 32610, Perak, Malaysia
}

\begin{abstract}
The landscape is an important national resource outstanding natural and cultural inheritance which is widely appreciated. This study attempts to evaluate visual landscape of Taiping District in relations to the larger landscape scale in Peninsular Malaysia. A Landscape Character Assessment was conducted on the visual landscape taken for several points in Taiping, Perak and surrounding area to see changes in the landscape. The aim of this study is to provide a visual structure for landscape classification of the Taiping District area that will contribute to the decision making in development and management in Malaysia. Ensuring the opportunity taken during district planning processes is important.
\end{abstract}

Keywords: Landscape character assessment, visual landscape, landscape structure

ISSN: 2398-4287@ 2017. The Authors. Published for AMER ABRA by e-International Publishing House, Ltd., UK. This is an open access article under the CC BYNC-ND license (http://creativecommons.org/licenses/by-nc-nd/4.0/). Peer-review under responsibility of AMER (Association of Malaysian Environment-Behaviour Researchers), ABRA (Association of Behavioural Researchers on Asians) and cE-Bs (Centre for Environment-Behaviour Studies), Faculty of Architecture, Planning \& Surveying, Universiti Teknologi MARA, Malaysia

\subsection{Introduction}

The landscape is understood as an area, as perceived by people, whose character is the result of the action and interaction of natural and or human factors (European Landscape Convention, 2000). The landscape is a complex system that has another challenging characteristic: material resources and populations distributed in space (Allain et.all, 2017). A combination of a human relationship with the existence of natural characters and elements in a landscape was known as a landscape character. Landscape character can define as a distinct, recognisable and consistent pattern of elements in the landscape. One landscape different from another, rather than better or worse, and also rates essentially, landscape character is that which makes an area unique (Swanwick, 2002). In other words, it understood that arises from the particular pattern of the different components combinations that can provide a sense of place to our surroundings (The Countryside Agency, 2005).

Landscape Character Assessment (LCA) is an indicator or integrated solution that effectively identified in the planning, development and management of the landscape. Landscape Character Assessment (LCA) can define as a way to identify what makes a place unique and can serve as a framework for decision-making that respects naturalness. It also provides a mechanism by which local communities and stakeholders can contribute towards the decisions that affect their local surroundings (European Landscape Convention, 2000). It also described as a distinct and recognisable pattern of elements that occur consistently in a particular type of landscape (Swanwick, 2004).

Viewing the landscape as a spatialized social-ecological system allows identification of specific management challenges: integration of multiple views, multiple levels of the organization, complex spatial-temporal patterns and uncertainties (Allain et.all, 2017). Each landscape elements were forming components and structures whose character is the result of the action and interaction of natural and/or human factors (European Landscape Convention, 2011). In previous studies, the purpose of this assessment is basically to protect, manage and develop the landscape (Devon County Council, 2002).

All European Union countries have conducted their assessment of landscape character (Fáilte Ireland, 2007). However, most of the countries in Asia, especially in South-East Asia not exposed to the landscape character assessment approach. Only a few Asian

\footnotetext{
* Corresponding author. Tel.: 013-2987616

E-mail address: mohdz841@perak.uitm.edu.my
}

ISSN: 2398-4287@ 2017. The Authors. Published for AMER ABRA by e-International Publishing House, Ltd., UK. This is an open access article under the CC BYNC-ND license (http://creativecommons.org/licenses/by-nc-nd/4.0/). Peer-review under responsibility of AMER (Association of Malaysian Environment-Behaviour Researchers), ABRA (Association of Behavioural Researchers on Asians) and cE-Bs (Centre for Environment-Behaviour Studies), Faculty of Architecture, Planning \& Surveying, Universiti Teknologi MARA, Malaysia

DOI: http://dx.doi.org/10.21834/e-bpj.v2i5.698 
countries such as Hong Kong and South Korea emulate the EU countries by establishing an assessment for the landscape character to preserve, conserve and control the landscape changes.

The landscape changes are particularly evident and significant in small and rapidly developing countries, with a high diversity of natural and cultural landscapes (Trop, 2017). Currently, in Malaysia, there is no systematic planning tool available to describe, classify, evaluate and predict a location or resulting pattern on existing landscape (Samat, 2009). The current physical planning in Malaysia has no direct integration process with the visual landscape character distinctiveness. Also, resource and element of landscapes in Malaysia have not been given due attention and recognition holistically. Failure to descriptively describe the landscape characters has resulted in less understanding of the landscape in this country.

Landscape Character Assessment (LCA) has gained a significant recognition around the globe, the understanding of the challenges faced by planners and decision- makers in incorporating LCA processes and outputs in land-use planning remains insufficient (Trop, 2017). Landscape Character Assessment is a helpful tool for natural resources protection. For example in South Korea, studies demonstrate the collection and systematically analyse data to identify a landscape character and to establish their landscape characters. The landscape character was considered as a distinctive characteristic regarding physiographic, biography, ecological heritage, cultural pattern and recreational potential.

Landscape Character Assessment evaluates landscape character conditions emphasising on the major changes of the study area. In this landscape character assessment exercise, protection and enhancement of landscape play important roles, as these support biodiversity and have important environmental, economic and social functions for the human population (Forman, 1995; Selman, 2000). A visual landscape character assessment was conducted to evaluate the strength and describe the visual sensitivity, unity and quality of Taiping before any decision-making process.

The study area was at Taiping District, Perak, borders of Kedah and Pahang. A Taiping began as a small tin-mining town until it became the first capital of Perak. It is so rich historically that it is now known as the Heritage town. In the beginning, Taiping was known as Klian Pauh. The town which began only as a small Malay settlement attracted a lot of foreigners due to the discovery of tin in that area. The Tin first discovered when Long Jaafar's elephant, called Larut, was smeared with mud which contained the mineral. Hence the district is called Larut, a namesake after the elephant. Taiping originates from a Chinese word 'Tai-Ping' meaning forever peaceful.

\subsection{Methodology}

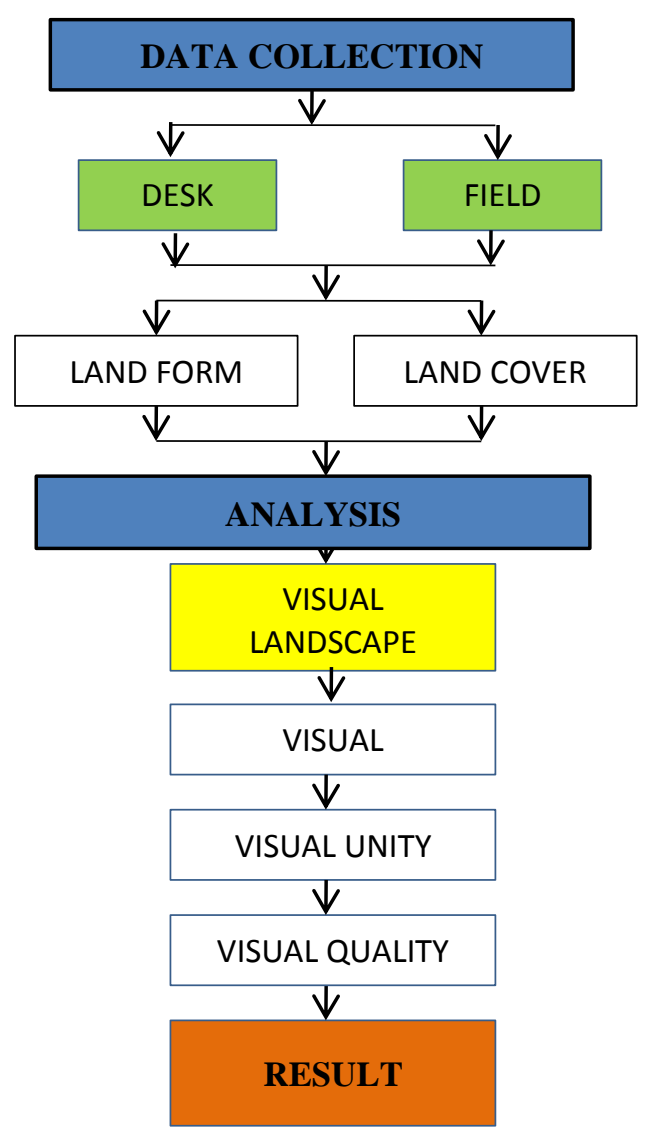

Figure 1: Landscape Character Assessment Methodology (Source: Author,2016) 
This study used the landscape character assessment methods developed in Europe and adapted it to the phenomenon, situation, and condition in Malaysia. This study combined the GIS method and the field survey as it was the practical solution for landscape characterization (Brabyn, 2005). This research conducted using a regional scale because of the size of the landscape and the resolution or spatial units at which the landscape analysed can lead to different results (Shifley et al., 2008, Sutton, 2011, Angeler et al., 2008 and Cañas et al., 2009). It is necessary to perform the evaluation of a smaller area on a scale of 1:10,000 - scale $1: 25,000$ or a more specific and localised, such as farms, parks or on proposed development area. At a local scale, it is important to set the reference base in the context of landscape character assessment in high details, to indicate types of landscape character.

Information on landform and land cover was obtained using GIS. The results produce the landform map and land cover map. The topographic map and slope map were overlaid to produce a landform map. Meanwhile, the land cover map was obtained using the satellite images by analysing attributes such as the land vegetation cover (agriculture, forest, mix agriculture and commodity crops) and built environment land cover (settlement, industry, urban, suburban, village and commercial). The land cover map contains the land cover information that occurs in the study area. Finally, the landform map was overlaid with the land cover map to produce the preliminary landscape character of the study area.

Field survey is a ground truthing approach to record information and photographs the actual landscape character to test and certify the preliminary character of the landscape. This field data is to get the intensity of landscape character area by assessing the visual landscapes that include Visual Sensitivity, Visual Unity and Visual Quality. An assessment form was developed based on criteria such as elements (diversity of landscape on the level of the element), characteristics (shape level as the expression of the individuality of the landscape) and character (as the holistic impression of space) (Jessel, 2006).

\subsection{Result - Landscape character}

Landscape Assessment also can be defined as all the ways of looking at describing, analysing and evaluating the landscape. (Makhzoumi and Pungetti, 1999). A suitable approach for landscape assessment was sought to characterise the landscapes, to describe the main forces of change and assess their biodiversity values by existing or easily derived information (Kim, 2007) and has to prepare the designation of special areas for specific forms of land use. The assessment results are the basis for the enforcement of sustainable land use.

Landscape character assessment is a powerful tool to aid the planning, design, development and management. Addressing the characterization process involving identifying, mapping, classifying and describing landscape character and the process of making a judgment based on landscape character to inform the range of decision. This approach influence process of managing and planning the landscape in these countries used as guidance in various study areas. It is not just rank or judge the character of places, and it simply records in a systematic way (landform, underlying geology and soil).

\subsection{Result of Landscape Character Types}

In this study, 4 (four) different landscape character types were proposed for the Taiping area (Map. 1).

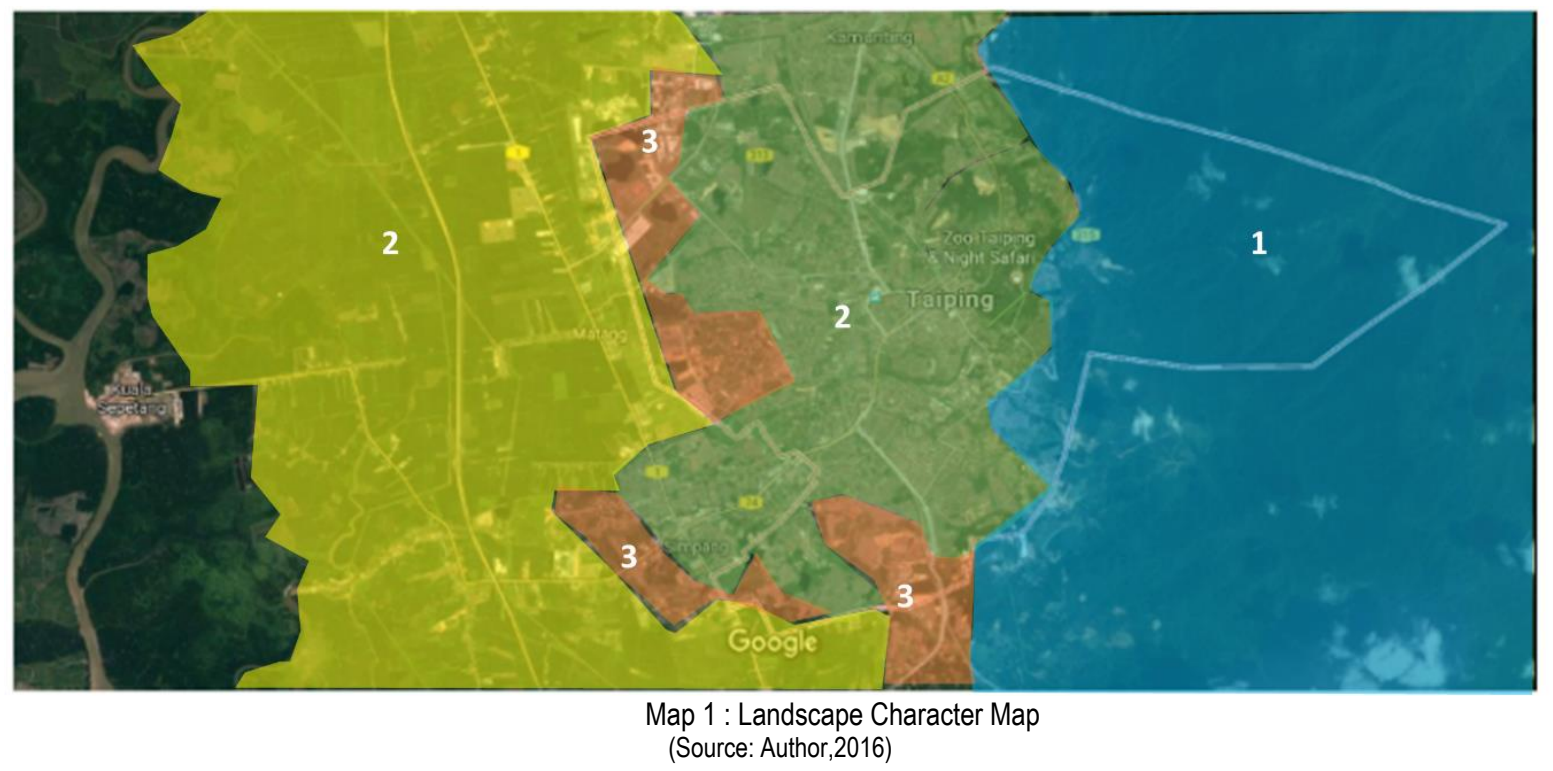

1. Natural Area at Highland - consists of the Banjaran Titiwangsa including Bukit Larut. The landscape character shows its natural beauty, rich in biodiversity, flora and fauna. Forest vegetation types vary according to the height of the Bukit Larut with a height of 1036 meters (montane forest or also known as deciduous forests). Moreover, hill dipterocarp forest is a forest in the hills with heights between 30 to $762 \mathrm{~m}$, while the dipterocarp forest between 762 to $1200 \mathrm{~m}$. 
2. Mass Agricultural Scale at Undulating Land - The second type of landscape is the agriculture area. It located at the foothills of Banjaran Titiwangsa. This character area has predominantly undulating land and covered by secondary forest as land cover. The slightly undulating terrain is a suitable condition for agriculture activity. It also characterised as planned agriculture governed by the local conglomerate.

3. Mixed Agricultural and Settlement of Undulating Land- It is a mixed area between the village settlements and estate with small farms surrounding at the foothills of Banjaran Titiwangsa. It was the Malay traditional villages which existed a long time ago. Settlements were growing as the population of the surrounding area is increasing. The character landform is undulating and some areas with flat terrain.

4. Urban and Settlement at Lowland - In the surrounding area of Taiping District are urban and emerging planned settlements. It located within an area which mostly flat. The area is growing with an establishment of educational institutions. Residential areas have also started growing, and small towns began to develop.

Overall, Taiping District has various characters to be identified either regarding of urban, settlement, agriculture or natural. Mass agricultural and urban sprawl becomes significant pressure changes, causing essential forces on the natural and local landscape character. In particular, housing and infrastructure are causing the original character changed radically.

\subsection{Result of Visual Landscape Character}

The Visual Landscape Character assessed in this study includes the Visual Sensitivity, Visual Unity, and Visual Quality. A rating system was used to evaluate the Visual Sensitivity, Visual Unity and Visual Quality (Table 1, Table 2 and Table 3).

\section{a) Visual Sensitivity - Distance Zone}

Visual sensitivity analysis was used to determine a model that can viewed from different perspectives. It distinguished visual hierarchy known as the distance zone consisting of a foreground, middle ground and background. Methodologies regarding landscape character distance zones to make the rating based on the following criteria:

Table 1: Definition of Visual Sensitivity Attribute for Taiping

\begin{tabular}{ll}
\hline Visibility & \multicolumn{1}{c}{ Criteria } \\
\hline Foreground & $\begin{array}{l}\text { A clearest and have a strong influence on the type of landscape (Mass agriculture scale at } \\
\text { undulating land) that is valued in Taiping. In the top of the mountain, the foreground is natural } \\
\text { (Natural at Highland). } 0-2 \mathrm{~km}\end{array}$ \\
\hline Middleground & $\begin{array}{l}\text { Simple view is clear and has some influence on the type of landscape that is valued. The area is } 2-5 \mathrm{~km} \\
\text { in the middle of the Taiping. It is dominant of mass agriculture at foothills. }\end{array}$ \\
\hline Background & $\begin{array}{l}\text { No clear view has any influence on the type of landscape that is valued. Visual distance is far }>5 \mathrm{~km} \\
\text { away and only can see the monochrome landscape character in Taiping. }\end{array}$ \\
\hline
\end{tabular}

(Source: Author,2016)

b) Visual Unity

Visual unity landscape character method based on the criteria in the following table:

Table 2: Definition of Visual Unity Attribute for Taiping

\begin{tabular}{ll}
\hline \multicolumn{1}{c}{ Visual Unity } & Criteria \\
\hline Harmonized & $\begin{array}{l}\text { Observers can see a dynamic and high rate of visual Unity when each component in the landscape in balanced merges. It is included the } \\
\text { natural character of Taiping. That visual is harmonised with the natural character. }\end{array}$ \\
\hline Clarity & $\begin{array}{l}\text { Observers can see each element in the composition of the landscape with clear and distinct. In is clearly identify the physical landscape } \\
\text { character in Taiping especially at Banjaran Titiwangsa (Natural Area at Highland, Mass Agricultural Scale at Undulating Land, Mixed } \\
\text { Agricultural and Settlement of Undulating Land and Urban and Settlement at Lowland) }\end{array}$ \\
\hline Uniqueness & $\begin{array}{l}\text { Observers can see each element in the composition and unique landscapes in the area. In Taiping, the uniqueness of this area is the } \\
\text { view of a natural area and the setting of mass agriculture. }\end{array}$
\end{tabular}

(Source: Author,2016) 
c) Visual Quality

Visual quality methods such as the following table.

Table 3: Rating and Definition of Visual Quality Attribute for Taiping

\begin{tabular}{|c|c|c|c|c|}
\hline \multirow{2}{*}{\multicolumn{2}{|c|}{ MAIN FACTOR }} & \multicolumn{3}{|c|}{ RATING SCORE CRITERIA } \\
\hline & & HIGH(3) & MODERATE (2) & LOW (1) \\
\hline & Landform & $\begin{array}{l}\text { Dominant terrain, unique and an } \\
\text { attractive view (slopes are steep, vertical } \\
\text { hills, large rock outcrop or interesting } \\
\text { landform) }\end{array}$ & $\begin{array}{l}\text { Landform with interesting features, } \\
\text { but less dominant }\end{array}$ & $\begin{array}{l}\text { Landform that is not } \\
\text { interesting without the } \\
\text { characteristics of an attractive } \\
\text { landscape. (wavy, low or flat) }\end{array}$ \\
\hline 2. & Vegetation Land Cover & $\begin{array}{l}\text { Have a diversity of vegetation regarding } \\
\text { species, colours, natural, agriculture and } \\
\text { sizes }\end{array}$ & $\begin{array}{l}\text { Part of the diversity of species, } \\
\text { colours and sizes which are } \\
\text { dominated by one or two types of } \\
\text { plants }\end{array}$ & Few or no diversity of plant \\
\hline 3. & Settlement & $\begin{array}{l}\text { Views of the settlement in harmony with } \\
\text { the environment (villages) }\end{array}$ & $\begin{array}{l}\text { View of settlement in harmony with } \\
\text { surrounding moderate }\end{array}$ & $\begin{array}{l}\text { Views of the settlement chaos } \\
\text { and not in harmony with the } \\
\text { environment }\end{array}$ \\
\hline 4. & Views of the Adjacent & $\begin{array}{l}\text { Views about which improve the quality of } \\
\text { the overall view }\end{array}$ & $\begin{array}{l}\text { Views about the medium affects } \\
\text { the sight of the whole area }\end{array}$ & $\begin{array}{l}\text { No effect of view about the } \\
\text { quality of visual }\end{array}$ \\
\hline
\end{tabular}

(Source: Author,2016)

Table 4: Rating for Evaluation Visual Quality Attribute in Landscape Character for Taiping

\begin{tabular}{cll}
\hline \multicolumn{1}{c}{ Value } & \multicolumn{1}{c}{ Criteria } & Justification \\
\hline HIGH & $\begin{array}{l}\text { The area has a high value of visual sensitivity, visual } \\
\text { unity and visual quality. }\end{array}$ & $\begin{array}{l}\text { The existence of a high visual sensitivity, visual } \\
\text { Unity and quality visual landscape that makes the } \\
\text { area interesting landscape and help to the } \\
\text { distinctive landscape character. }\end{array}$ \\
\hline MODERATE & $\begin{array}{l}\text { The area has a moderate value of visual sensitivity, } \\
\text { visual quality and visual Unity. }\end{array}$ & $\begin{array}{l}\text { The existence of visual sensitivity, visual quality and } \\
\text { visual Unity the landscape that moderation. }\end{array}$ \\
\hline LOW & $\begin{array}{l}\text { The area has a low value of visual sensitivity, visual } \\
\text { quality and visual Unity. }\end{array}$ & $\begin{array}{l}\text { The existence of visual sensitivity, visual quality and } \\
\text { visual Unity the landscape that low. }\end{array}$ \\
\hline
\end{tabular}

(Source: Author,2016)

\section{d) Overall Result Landscape Character Strengths Evaluation}

Results of this assessment were to view the strength of a landscape character regarding Visual Sensitivity, Visual Quality and Visual Unity. Areas with high visual value will have an opportunity to be of high potential areas as areas of distinctive landscape character. Analysis of character is the relationship of human perception and attitude towards the visual environment. Mental entities play a major role in providing significant value to the strength/weakness of the landscape's character through visual and aesthetic dimensions. The assessment which then recorded in form was made based on the sensitivity, union as well as the visual quality.

Table 5: Interpretation/justification for the strength of landscape character

\begin{tabular}{ll}
\hline \multicolumn{1}{c}{ Factor } & \multicolumn{1}{c}{ Interpretation } \\
\hline Visual & $\begin{array}{l}\text { Evaluate the foreground, middle ground and background to interpret the visual structure of the scene. The area included in the view that } \\
\text { sensitivity } \\
\text { close to the observer is considered in the high visual sensitivity and the sensitivity will be reduced for the area (zone) middle and back. It } \\
\text { clearly identifies and classifies foreground, middle ground and background view for Taiping (see Image 1 and 2). This image is clearly } \\
\text { identified view from highland to lowland and lowland to highland. }\end{array}$ \\
\hline Visual unity & $\begin{array}{l}\text { Evaluate and rank the visual unity aesthetic elements in the area/landscape regarding visual harmony, clarity of the natural order and } \\
\text { man-made components (culture) and the unique elements of the existing or to exist in Taiping. Natural vegetative and agricultural } \\
\text { vegetative is a dominant visual harmony, clarity and uniqueness for this study area. }\end{array}$ \\
\hline $\begin{array}{l}\text { Visual Quality } \\
\text { of the landscape regarding the order of observation elements and the natural and cultural components. Taiping is more greenery area } \\
\text { including natural and agriculture. There are some settlement areas in the foothills and villages, but it still blends with nature. The } \\
\text { landform of the study area can clearly identify, and views of the adjacent harmonise with the area. }\end{array}$
\end{tabular}

(Source: Author,2016) 


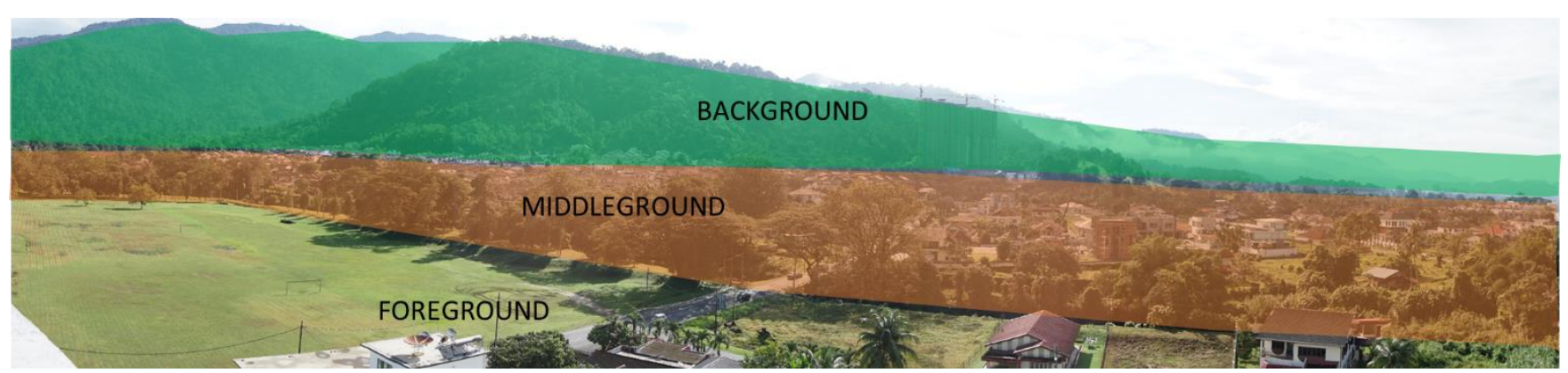

Image 1 : View from Lowland to Highland

(Source: Author,2016)

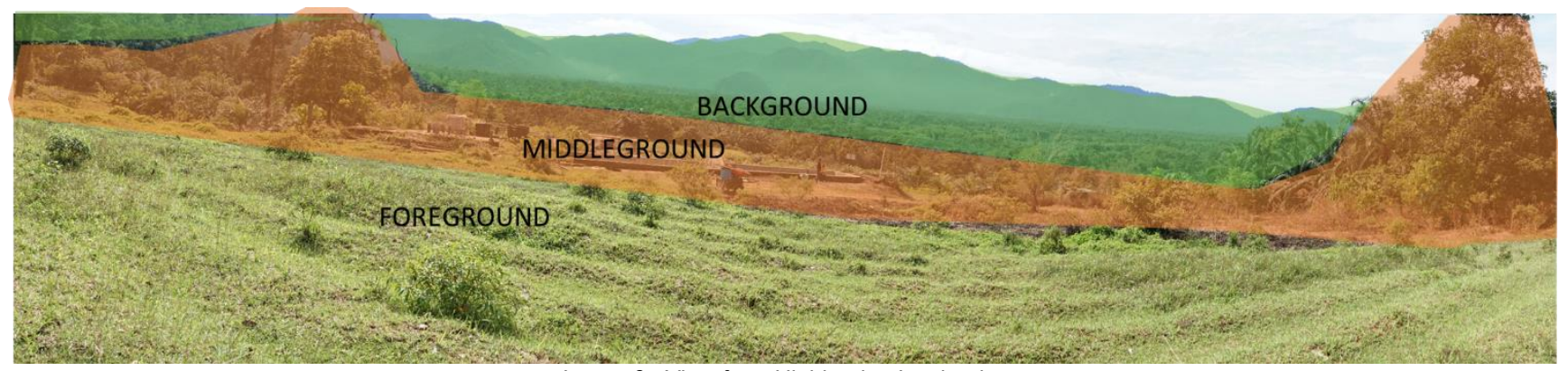

Image 2 : View from Highland to Lowland

(Source: Author,2016)

\subsection{Discussion}

The landscape was seen widely as significant elements of the natural planning and protection agenda, covering various aspects of quality of life. The agenda of natural planning and protection pressure and to some extent will affect the landscape changes. Based on the formation of an organisation of recognises landscape is important and contributes to the community especially in Taiping. Today, there is less effort and enforcement to maintain the landscape sensitivity and sense of place. Malaysia particularly and Asia generally should have the initiative to create a declaration that will provide guidelines and education to the public about the importance of landscapes European Landscape Convention (ELC) as a model when a majority of European Union countries agreed in the interests of landscape holistically. The ELC declaration, for example, describes the structure for its implementation to provide the protection, management and natural landscape planning in Europe.

The main action of the convention is (i) to raise the performance of the structural framework of the existing laws and regulations; (ii) to influence legislation, rules and recommendations that will be plan in the future; (iii) to increase understanding and to monitoring natural landscape character changes and trends in the landscape; and (iv) involving the community through a comprehensive awareness and understanding, as well as through promotion, education and training and sharing experienced (European Landscape Convention, 2007). For example in Taiping. There beautiful natural area it is considered to preserve and protect. So, there are need some statement or declaration will support the efforts of natural landscape area programme. In the declaration, EU countries agreed to state that natural landscape was important, not just as scenery or background image, but also as a relationship with the heritage elements. Natural landscape also has lots of value and become relevant for humans. Emphasis on the landscape occurred in all aspects and any circumstances whether land, inland water, tidal, ocean, nature, rural, urban and suburban areas, and degraded.

Creating a declaration in Malaysia is important so that all relevant organisations or stakeholders will be able to see the benefits from the natural landscape. It might be set up on a small scale, first to highlight the impact and indirect role models in the wider area. Besides, government or private organisations such as corporate law, national bodies, regional bodies, local governments and nongovernment organisation, utility companies and major landowners should take this opportunity in bringing more sustainable landscape development regarding natural landscape protection.

The idea is to help organisations more sensitive to the environmental, social and economic development. It is expected that the landscape character assessment and the idea of forming this declaration will contribute to raising the profile of natural landscape and more sensitive in disclosing any decisions and actions affecting the landscape. The idea of this concept is not intended to oppose the development but to make development more delicate and distinctive. The decision is made by the plans, policies, and strategies available.

\subsection{Conclusion}

Landscape character assessment is a systematic approached to analyse information and spatial data for natural landscape planning and protections in Taiping. It is also as a bridge between scientific knowledge and socio-economic issues needed to meet the demands of sustainable landscape planning and management. Information on the relationships between landscape structure and 
functions allows land use planners to model and predict the impacts of planned activities on ecological systems, and then to provide results or alternatives regarding quantitative data. This mechanism is used to help make decisions on the sustainable development of land use aspects will come up with a different approach from the physical planning Gazette earlier. It is a holistic approach in highlighting various sources of data either natural resources, Taiping. The results of landscape characterization in Taiping highlight the diversity, sensitivity and distinctiveness of the area. Landscape character analysis is an important step in the planning process. The landscape is the substrate and context in any action. Aesthetic qualities of naturalness, which are highly valued by society, determine the outcome of landscape planning. Therefore, to plan a harmonious landscape, we must have a thorough understanding of its competition and patterns. If we do not consider landscape character, we will run a risk of superimposing patterns which will damage the unity and its Genius Loci. Landscape character assessment can help to resolve potential land use in future landscape development. Thus, this early study should be regarded as a positive first step in changing a landscape planning concept to make it more sustainable. However, the results of this study were sufficient to show that the landscape character assessment approach provides a valuable contribution to a sustainable landscape planning policy, to control development, to provide protection to the sensitive landscape, landscape character conservation, preservation of distinctive areas, and sustained sense of place and biodiversity conservation. Also, the use of landscape character indicators for describing and assessing changes has been widely tested in Malaysia.

\section{Acknowledgement}

The work in this research is funded by Ministry of Higher Education (Malaysia) under Research Acculturation Grant Scheme (600RMI/RAGS 5/3 (132/2014)). The authors would like to acknowledge Institute of Research Management and Innovation (IRMI), Universiti Teknologi MARA for providing necessary assistance for the preparation of this research.

\section{References}

A. Lausch, F. Herzog. (2002). Applicability of landscape metrics for the monitoring of landscape change: issues of scale, resolution and interpretability. Ecol. Indic., 2 (1), pp. 3-15

Abrahamsson, K. V. (1999). Landscapes Lost and Gained: On Changes in Semiotic Resources. Human Ecology Review, Vol. 6, No. 2, 51-61.

Allain. S, Plumecocq. G, Leenhardt. D, (2017). How Do Multi-criteria Assessments Address Landscape-level Problems? A Review of Studies and Practices. Ecological Economics, Volume 136, Pages 282-295.

Antrop, M. (2006). From holistic landscape synthesis to trans-disciplinary landscape management. Chapter 3 in "From Landscape Research to Landscape Planning: Aspects of Integration, Education and Application" A. Tress, G Tress, G. Fry and P. Opdam (eds). Springer.

Antrop, M. , Eetvelde, V. V. (2009). A stepwise multi-scaled landscape typology and characterisation for trans-regional integration, applied on the federal state of Belgium. Landscape and Urban Planning. 91, Issue 3, 160-170.

Bastian, O. (2000). Landscape classification in Saxony (Germany)—A tool for holistic regional planning. Landscape and Urban Planning 50, 145-155.

Bastian, O. , RoĖder, M. (1998). Assessment of landscape change by land evaluation of past and present situation. Landscape and Urban Planning $41,171-182$.

Brabyn, L. (2005). Solutions for characterising natural landscapes in New Zealand using geographical information systems, Journal of Environmental Management, 76 23-34.

Brabyn, L. (2009). Classifying landscape character, Landscape Research, 34(3), 299- 321.

Bryant, M. (2001). Illuminating the Position of Landscape Planning Today: Decline and Potential Rebirth. Landscape Architecture and Regional Planning. Amherst. University of Massachusetts. Unpublished PhD: pp. 187. 
Countryside Agency (2005). Report: A character assessment of Oxford in its landscape setting. Countryside Agency Publications, Wetherby.Countryside Agency and Scottish Natural Heritage.

Countryside Agency. (1999). Countryside Character Volume 8: South West, The Countryside Agency.

Countryside Council for Wales. (2001). Guide to Best Practice in Seascape Assessment. University College Dublin : Maritime Ireland/Wales Interreg, Report No. 5.

Devon County Council and Steve Church. (2002). The Devon Landscape - An appraisal of Devon's Landscape at the beginning of the 21st Century, Devon Books.

Dikau, R., Brabb, E.E., Mark, R.M. (1989). Landform classification of New Mexico by computer, U.S. Department of Interior, U.S. Geological Survey. Open-File report, 91-634.

European Landscape Convention. (2000). The European Landscape Convention, European Treaty, Series No. 176.

European Landscape Convention. (2007). Report: The European Landscape Convention Framework of Implementation in England.

F. Weyland, P. Laterra. (2014) Recreation potential assessment at large spatial scales: a method based in the ecosystem services approach and landscape metrics. Ecol. Indic., 39, pp. 34-43.

Fáilte Ireland (2007), Feasibility Study to Identify Scenic Landscapes in Ireland, National Tourism Development Authority. MosArt. Local authority survey results and focus group meetings findings.

Hawkins, V. , Selman, P. (2002). Landscape scale planning: exploring alternative land use scenarios. Landscape and Urban Planning60(4), 211-224.

Jellema, A. , Jeroen, C.J., Groot, B.,Walter, A.H. (2009). Designing a hedgerow network in a multifunctional agricultural landscape: Balancing trade-offs among ecological quality, landscape character and implementation costs. European Journal of Agronomy, 112-119.

Jessel, B. (2006). Elements, characteristics and character - Information functions of landscapes in terms of indicators. Ecological Indicators 6, $153-167$.

Kim, K.H. , Pauleitb, S. (2007). Landscape character, biodiversity and land use planning: The case of Kwangju City Region, South Korea, Land Use Policy 24, 264274.

Landscape Character Assessment: guidance for England and Scotland. Countryside Agency and Scottish. (2001). Natural Heritage, Wetherby. Environment and Heritage Service.

Makhzoumi, J., Pungetti, G. (1999). Ecological Landscape Design and Planning. London : E \& FN SPON.

Moore-Colyer, R. , \& Scott, A. (2005). What kind of landscape do we want? Past, present and future perspectives. Landscape Research 30(4), 501-523.

Mücher, C.A. (2003). Identification and Characterisation of Environments and Landscapes in Europe. Wageningen : Alterra rapport 832, Alterra.

Ode, Å., Fry, G., Tveit, M.S., Messager, O., Miller, D. (2007). Indicators of perceived naturalness as drivers of landscape preference, Journal of Environmental Management, 1-9.

Samat, N. (2009) Integrating GIS and CA-MARKOV model in evaluating urban spatial growth. Malaysian Journal of Environmental Management, 10 (1), 83-99.

Selman, P. (2000). Landscape sustainability at the national and regional scales. In: Benson, J.F., Roe, M.H. (Eds.), Landscape and Sustainability. London : Spon Press.

Swanwick, C. (2002). Landscape Character Assessment. Guidance for England and Scotland, Countryside Agency and Scottish Natural Heritage publication.

Swanwick, C. (2004). The assessment of countryside and landscape character in England: an overview. In: Bishop, K., Phillips, A. (Eds.), Countryside Planning.

Trop. T (2017). From knowledge to action: Bridging the gaps toward effective incorporation of Landscape Character Assessment approach in land-use planning and management in Israel. Land Use Policy. Volume 61, Pages 220-230 